\title{
STRATEGIC ALIGNMENT IMPACTS ON ORGANIZATIONAL PERFORMANCE IN INDONESIAN BANKING INDUSTRY*
}

\author{
Nofie Iman \\ Jogiyanto Hartono
}

Strategic alignment has attracted the attention of researchers and practitioners for the last 15 years. This paper reports findings from a survey on the impacts of strategic alignment on organizational performance in the Indonesian banking industry. The survey was conducted through internet-based and postal questionnaires sent to selected companies.

Structural Equation Modeling (SEM) is utilized to apprehend the strategic alignment concept as an emergent variable derived from the co-variation of level of business strategy and level of IS/IT strategy. Hence, we explore the role of this emergent concept as a determinant of organizational performance. Analysis of the data reveals a generally positive impact towards the organizational performance.

Keywords: banking industry; organizational performance; strategic alignment

* An earlier version of this paper was presented at the Simposium Nasional Akuntansi IX, Padang, Sumatera Barat, 23-26 August 2006. 
Iman \& Hartono-Strategic Alignment Impacts on OrganizationalPerformance...

will let banks get closer to customers, deliver a wider range of services at lower costs, and streamline internal systems, so that all customer data is integrated and can be used to spot trends that can lead to new products. The Web will offer banks great opportunities-It will be interesting to see which banks step up to this opportunity."'

\section{Rationales}

With respect to a company's strategic policies, ICT has played an important role in the organization's existence. Previous research has found that the information system strategy is now considered equal with business strategy (Hirschheim and Sabherwal 2001). In other discussions, information systems are appreciated for making significant contributions to a company's strategic alignment (Camponovo and Pigneur 2004). Furthermore, an excellent strategic alignment of business strategy and information systems strategy will lead the information system to a crucial point, which eventually boosts business performance (Hirschheim and Sabherwal 2001).

Strategic alignment of business strategy and information technology/ system strategy will respond to the challenge to the company faced with stiffer competition. Teo and King (1999) assert that the importance and integration use of business planning- information system's planning (BPISP) has been empirically proven to increase the information systems contribution to company performance. Unfortunately, the investment value of the information systems cannot be fully realized owing to the lack of strategic alignment between business strategy and information systems strategy in the company (Henderson and Venkatraman 1993). Hence, an increase in performance and competitive advantage will be difficult to accomplish.

This research assumes that the use of information systems is a fundamental issue in every business, especially in the banking sector. Strategic alignment -which is one of the hot topics in information systems- is also new and compelling, especially in terms of its implementation in Indonesia.

For that purpose, empirical evidence is required to assess the correlation of information technology/systems alignment to business strategy and organizational performance (Sabherwal and Chan 2001). Similarly, Camponovo and Pigneur (2004) mention that analogous research on different environments and at different times is still needed to find the dynamic changes and to evaluate the general patterns that might emerge.

This research is expected to make theoretical and practical contributions. Theoretically, this study tests the pre-

\footnotetext{
${ }^{1}$ Bill Gates. 1997. "No one is really living a Web Lifestyle-Yet," New York Times, July 29, 1997; available on www.htimes.com/today/access/columns/0729bill.html.
} 
Iman \& Hartono-Strategic Alignment Impacts on OrganizationalPerformance...

Figure 1. Strategic Alignment Model

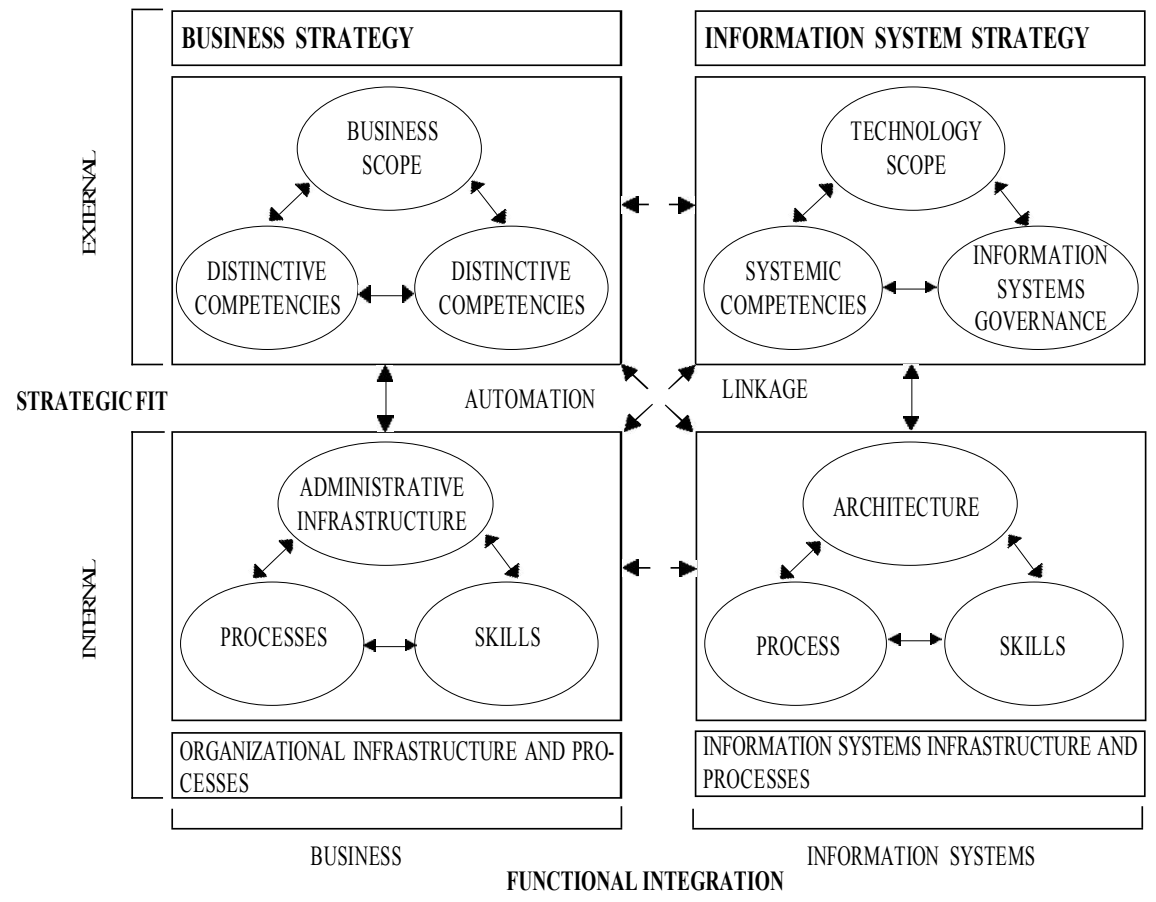

Source: Henderson, J. C., and N. Venkatraman (1993). Strategic Alignment: Leveraging Information Technology for Transforming Organizations. IBM Systems Journal, 32 (1): 4-16.

examine the strategic alignment concept and demonstrate that a positive linkage exists between alignment and performance.

The term "strategic alignment" consists of the words "alignment" and "strategy." Alignment is coordination achieved when the company information technology/systems strategy is derived from the organization strategy (Lederer and Mandelow 1989), comprising:

- content linkage, referring to the consistency of business plan and information technology/systems plan,

- timing linkage, referring to whether the information technology/systems plan is developed after, along with, or before the business plan is made, - personnel linkage, referring to different participants' involvement degree in the planning of business and information technology/systems area.

In the meantime, strategy can also represent "objectives" (Reich and Benbasat 1996), "plan" or "planning" (Teo and King 1997). In this discussion, the strategy consists of:

- information technology/systems strategy, which is the main choice emphasizing the implementations and uses of technology-based information systems in a company 
Iman \& Hartono-Strategic Alignment Impacts on OrganizationalPerformance...

vantage will be attained, leading the banking sector to survive and thrive despite fierce competition.

\section{The Effect of Strategic Alignment on Organizational Performance}

Much literature has also emphasized the effect of strategic alignment on organizational performance. Chan et al. (1997) states that "Companies that appear to perform best are companies in which there is alignment between realized business strategyand realized information systems strategy" (p. 142). Luftman and Brier (1999) similarly declares, "Companies that have achieved alignment can build a strategic competitive advantage that will provide them with increased visibility, efficiency, and profitability to compete in today's changing markets" (p. 121).

Unfortunately, a positive correlation between strategic alignment and organizational performance tends to be diverse. Sabherwal and Chan(2001) point out, "Empirical research on the performance implications of this alignment has been sparse and fragmented" (p. 21). Likewise, Brynjolfsson and Hitt (1998) claim, "While the average returns to IT investment are solidly positive, there are huge variations across organizations, some havespent vast sums on IT with little benefit, while others have spent similar amounts with tremendous success" ( $\mathrm{p}$. $50)$.
Therefore, evaluations on the effect of strategic alignment on organizational performance are still needed. Bruce (1998) asks, "If alignment is needed to facilitate optimum business benefit, how do we know when we have it? It is important to look at the impact IT is having on business results" (P. 17). Delone and McLean (1992) add that an evaluation on information technology/systems performance in organization is still one of the pivotal topics in the field of information systems.

\section{Research Model and Hypotheses Development}

The concept of strategic alignment is acquired from co-variation between a business strategy's importance level attributes and information technology/systems strategy's importance level attributes at a particular time.

Business strategy, according to Porter (1980), influences the company's positioning in its business area. Henderson and Venkatraman (1993) suggest that business strategy importance level is influenced by the company's strategic policies on "makeor-buy" decisions, partnership [BS1] and alliance [BS2]. Partnership refers to how much a company's business development depends on its strategic partners is. Alliance is the extent of business development's dependence on outsourcing activities.

In McFarlan et al. (1983); Knight and Silk (1990); and Das et al. (2001), 
Iman \& Hartono-Strategic Alignment Impacts on Organizational Performance...

Figure 2. Hypothetical Model

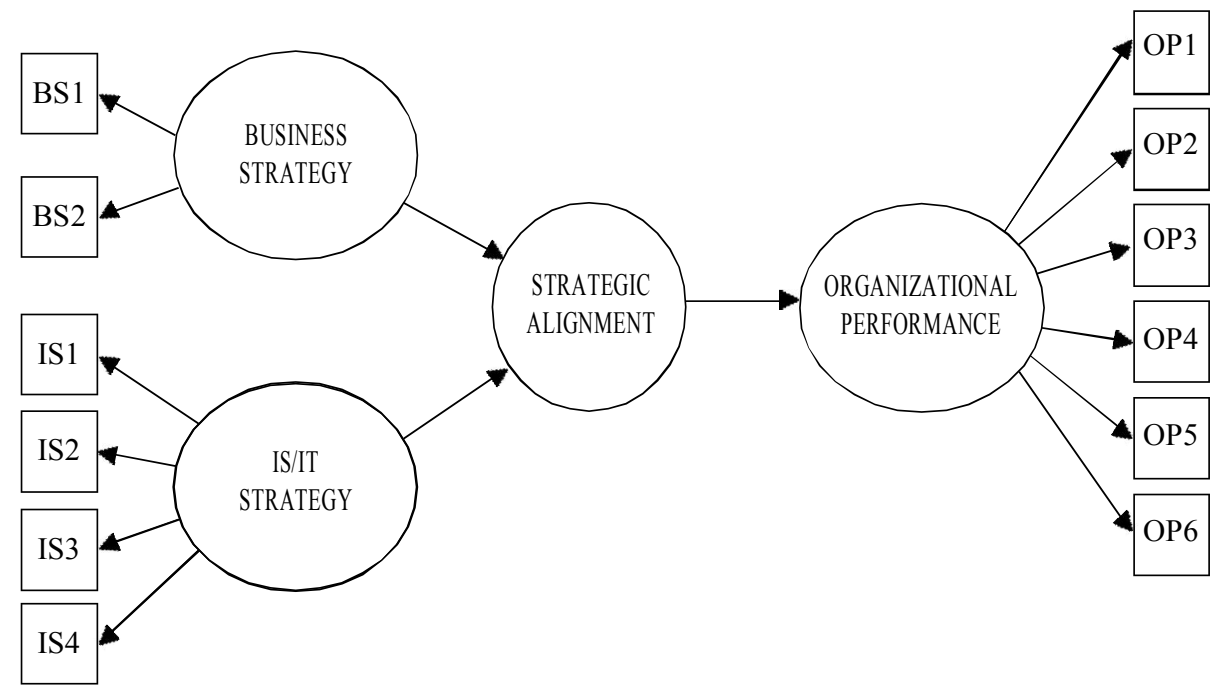

naires developed and tested by Kefi and Kalika (2005). The questionnaires were based on literature and previous research. Convenience sampling and snowball sampling methods were applied in this study.

Two rounds of pretests (initial and pilot tests) were conducted before using the survey instrument for data collection. All the variables (dependent and interdependent variables) were measured using a five-point Likert scale.

Reliability assessment was carried out using Cronbach's alpha in order to ensure that the variables comprising each proposed research construct were internally consistent. The coefficient alpha determines reliability based on internal consistency ranging from 0 to 1 ; a value between 0.60 and 0.70 is the lowest acceptance limit for reliability (Hair et al. 1998). Table 2 below shows that the reliability esti- mates are well above the acceptable threshold.

\section{Results and Analysis}

Data were collected using two methods mail-and internet-based. One hundred and twenty questionnaires were delivered via postal mail to top management to be filled out and faxed back. E-mail invitations to participate in the survey were also sent to 320 bankers throughout Indonesia. They could complete and return them by email attachments, or, they could fill it out through a web-based interface.

Five blank questionnaires were returned, with explanations pertaining to company policy or to confidentiality. Forty-four usable questionnaires were returned, yielding a response rate of 10 percent.

This is considered adequate, keeping in mind that practitioners of infor- 
Iman \& Hartono-Strategic Alignment Impacts on OrganizationalPerformance...

Table 2. Variable Characteristics

\begin{tabular}{lc}
\hline \multicolumn{1}{c}{ Variable } & Reliability* \\
partnership strategy choice & .7970 \\
alliance strategy choice & .8276 \\
strategic role perceptions & .8241 \\
systematic competencies & .8322 \\
architecture choice & .8162 \\
work process choice & .8160 \\
productivity & .8277 \\
cost reduction & .8236 \\
value-added innovation & .7985 \\
reactive ability & .8348 \\
responsiveness to customer needs & .8243 \\
collaborations with business partners & .8419 \\
\hline
\end{tabular}

* Reliability measure is Cronbach's Alpha

mation technology/systems, especially CIOs, tend not to respond to questionnaires (Hind 2001). Chetty (1996) who conducted similar quantitative research on small- and medium-scale enterprises in New Zealand finds similar resistance.

\section{Descriptive Statistics}

The majority of respondents (85.71 percent of the total) are men. The remaining 14.29 percent are women. Most respondents (62.86 percent) hold an undergraduate degree. The second largest percentage ( 31.43 percent) hold master's degrees, fol- lowed by the diploma holders (5.71 percent).

The largest percentage of the respondents $(71.43 \%)$, come from national banks, while 8.57 percent are from international banks. Regional banks, retail banks, and Bank Perkreditan Rakyat (BPR) comprise 2.86 percent of all respondents. The remaining, 11.43 percent are from other categories. ${ }^{3}$ The survey inquired into respondents' spending in IT investment, their perception of strategic alignment, and the dominant aspects of strategic alignment (refer to Table 3).

${ }^{3}$ These categorizations are based on banking classification formed by Bank Indonesia (2005) 
Iman \& Hartono-Strategic Alignment Impacts on Organizational Performance...

\section{Structural Equation Model Evaluation}

This research model has been examined by structural equation modeling, using AMOS 6.0. The constructs of business strategy, IS/IT strategy, and organizational performance are considered non-observed or latent variables, measured by specific observed variables.

The model proposed in the structural equation is estimated to acquire the goodness-of-fit value. An estimation on the model is summarized in Table 4.

Table 5 shows that all fit criteria have marginal estimation results. A criterion relatively close to the cutoff value is GFI, which is 0.88 . The AGFI's estimation result is 0.81 and that of TLI is 0.74 , while the recommended value is more than or equal to 0.90 . In the meantime, the RMSEA criterion is 0.10 , whereas the recommended value is equal to or less than 0.08 .

The constructs' causal relationship tests are shown by regression weight value in the critical ratio (c.r.) column, which are identical with testing results, t-count, using statistical tools. The conclusion is summated by comparing c.r. value with its critical value $( \pm 1.96)$ on five-percent significance rate.

$\mathrm{H}_{1 \mathrm{~A}}$ states that the level of business strategy has a direct influence on strategic alignment. $\mathrm{H}_{1 \mathrm{~B}}$ affirms that the level of information systems/technology strategy also has a direct influ-

Table 4. Structural Equation Model Evaluation

\begin{tabular}{|c|c|c|c|}
\hline Criterion & Cut-off Value & $\begin{array}{c}\text { Estimation } \\
\text { Result }\end{array}$ & Evaluation \\
\hline Chi-square $\left(\chi^{2}\right)$ & -120.535 & - & \\
\hline Significant probability & $\geq 0.05$ & .000 & Marginal \\
\hline RMSEA & $\leq 0.08$ & .105 & Marginal \\
\hline GFI & $\geq 0.090$ & .879 & Marginal \\
\hline AGFI & $\geq 0.90$ & .809 & Marginal \\
\hline TLI & $\geq 0.90$ & .744 & Marginal \\
\hline
\end{tabular}

Table 5. Regression Weight Calculation Results

\begin{tabular}{|c|c|c|c|c|c|}
\hline & & Estimate & S.E. & c.r. & $\mathbf{P}$ \\
\hline $\mathrm{H}_{1 \mathrm{~A}}$ & $\mathrm{SA}<\mathrm{BS}$ & 0.105 & 2.142 & 2.140 & 0.009 \\
\hline $\mathrm{H}_{1 \mathrm{~B}}$ & $\mathrm{SA}<\mathrm{IS}$ & 0.745 & 2.055 & 2.015 & 0.014 \\
\hline $\mathrm{H}_{2}$ & $\mathrm{OP}<\mathrm{SA}$ & 0.232 & 1.647 & 1.985 & 0.007 \\
\hline
\end{tabular}


Iman \& Hartono-Strategic Alignment Impacts on OrganizationalPerformance...

broad range and potential advantages. In the banking sector, strategic alignment is apparently feasible in the financial services industry, ${ }^{5}$ manufacturing process (combined with balanced scorecard), ${ }^{6}$ procurement domain, ${ }^{7}$ and higher education. ${ }^{8}$ Grant (2003), for instance, conducted research on the implementation of strategic alignment and enterprise systems. Bleistein et al. (2006) also studied strategic alignment through goal modeling and the problem diagram approach.

However, like every other piece of research, this research has several limitations which can affect the findings.

First and foremost, more reliable measures of the strategic alignment's impacts on organizational performance need to be improved since the subjectivity and indirect measurement do not provide the same strength as the direct objective measure does. More efforts are required to advance the theoretical development and enhance it through empirical validation.

Subsequent research should develop a larger sample such that the reliability and model-fit value can be strengthened. A site visit is also suggested as it will enable future researchers to obtain more comprehensive information. Site visit to the observed object using qualitative approach is highly recommended (Kefi and Kalika 2005). Future researches can also include contingency factors (such as management style, IT functionality, environment, etc.) and use a qualitative approach (e.g., case study). By means of theory expansion and development, a greater number of and more convenient theoretical and practical contributions are possible.

\section{Conclusions}

This research examines the relationship among strategic alignment factors and its influence on organizational performance in the banking sector. The research is based onHenderson and Venkatraman's (1993) strategic alignment model, on Van de Ven and Drazin's(1985), and on Venkatraman's (1989)co-variation perspectivemodel.

This study elaborates on previous research on strategic alignment and

\footnotetext{
5 Teubner, R. A. \& Mocker, M. 2005. Strategic Information Planning - Insight from an Action Research Project in the Financial Services Industry. Working paper No. 3, European Research Center for Information Systems, Eds. Becker, J. et al., April 2005.

${ }^{6}$ Decoene, V. \& Bruggeman, W. 2003. Strategic Alignment of Manufacturing Processes in a Balanced Scorecard-based Compensation Plan: A Theory Illustration Case. Working paper at Facultiet Economie en Bedrijfskunde, Gent, Belgium, October 2003.

${ }^{7}$ Versendaal, J., Beukers, M. \& Batenburg, R. 2005. Business Alignment in the Procurement Domain. Paper submitted to and discussed in Workshop Inkoop Onderzoek Nederland (WION), Lunteren, Netherlands, January 18-19, 2005.

${ }^{8}$ Pirani, J. A. \& Salaway, G. 2004. Information Technology Alignment in Higher Education. Educause Center for Applied Research (ECAR) Key Findings, June 2004.
} 
Iman \& Hartono-Strategic Alignment Impacts on OrganizationalPerformance...

The final, and the most important, point is that executives in the information technology/systems realm should share responsibility with senior execu- tives in other fields, because strategic alignment has been proven to improve the organizational performance.

\section{References}

Bank Indonesia. 2005. Statistik Perbankan Indonesia 3 (September). Bank Indonesia: Jakarta.

Bleistein, S. J., K. Cox, and J. Verner. 2006. Validating strategic alignment of organizational IT requirements using goal modeling and problem diagrams. Journal of Systems and Software 79 (3): 362-378.

Boar, B. H. 1994. Logic and information technology strategy: Separating good sense from nonsense. Journal of Systems Management 45 (5): 16-21.

Brancheau, J. C., B. D. Janz, and J. C. Wetherbe. 1996. Key issues in information systems management: 1994-95 SIM Delphi results. MIS Quarterly 10 (2): 225-242.

Bruce, K. 1998. Can you align business with strategy? Strategy and Leadership 26 (5): 16-21.

Brynjolfsson, E., and L. M. Hitt. 1998. Beyond the productivity paradox. Communications of the ACM 41 (8): 49-55.

Camponovo, G., and Y. Pigneur. 2004. Information systems alignment in uncertain environment. Paper presented at The IFIP TC8/WG8.3 International Conference: Decision Support in an Uncertain and Complex World.

Calhoun, K. J., and A. L. Lederer. 1990. From strategic business planning to strategic information systems planning: The missing link. Journal of Information Technology Management 1(1): 1-5.

Chan, Y. E., and S. L. Huff. 1993. Strategic information systems alignment. Business Quarterly: 55-51.

Chan, Y. E., S. L. Huff, D. W. Barclay, and D. G. Copeland. 1997. Business strategic orientation, information systems, strategic orientation, and strategic alignment. Information Systems Research 8 (2): 125-150.

Chetty, S. 1996. The case study method for research in small- and medium-sized firms. International Small Business 15 (1): 73-85.

Croteau, A. M., S. Solomon, L. Raymond, and L. Bergeron. 2001. Organizational and technological infrastructures alignment. Proceedings of the Hawaii International Conference on System Sciences. Hawaii: Maui.

Das, S. R., S. A. Zahra, and M. E. Warkentin. 1991. Integrating the content and process of strategic MIS planning with competitive strategy. Decision Sciences (22): 953984. 
Iman \& Hartono-Strategic Alignment Impacts on OrganizationalPerformance...

Luftman, J. N., P. R. Lewis, and S. H. Oldach. 1993. Transforming the enterprise: The alignment of business and information technology strategies. IBM Systems Journal 32 (1): 198-203.

McFarlan, E. W., J. L. McKenney, and P. Pyburn. 1983. The information archipelagoplotting a course. Harvard Business Review 61 (1): 145-156.

Mullineux, A. W., and V. Murinde. 2003. Handbook of International Banking. Cheltenham: Edward Elgar Publishing.

Porter, M. E. 1980. Competitive Strategy: Technique for Analyzing Industries and Competitors. New York: The Free Press.

Prahalad, C. K., and M. S. Krishnan. 2002. The dynamic synchroniztion of strategy and information technology. MIT Sloan Management Review 43 (4): 24-33.

Premkumar, G., and W. R. King. 1991. Assessing strategic information systems planning. Long Range Planning 24 (5): 41-58.

Premkumar, G., and W. R. King. 1992. An empirical assessment of information systems planning and the role of information systems in organizations. Journal of Management Information Systems 9 (2): 99-125.

Reich, B. H., and I. Benbasat. 1996. Measuring the linkage between business and information technology objectives. MIS Quarterly 20 (1): 55-81.

Reich, B. H., and I. Benbasat. 2000. Factors that influence the social dimension of alignment between business and information technology objectives. MIS Quarterly 24 (1): 81-113.

Rybczynski, T. 1997. A new look at the evolution of the financial system. In J. Revell (edt.) The Recent Evolution of Financial Systems. London: Macmillan.

Sabherwal, R., and Y. E. Chan. 2001. Alignment between business and IS strategies: A study of prospector, analyzers and defenders. Information Systems Research 12 (1): 11-33.

Sethi, V., and W. R. King. 1994. Development of measures to assess the extent to which an information technology application provides competitive advantage. Management Science 40 (12): 1601-1627.

Strassman, P. A. 1990. The Business Value of Computers. New Canaan, Connecticut: The Information Economics Press.

Tallon, P. P., K. L. Kraemer, and V. Gurbaxani. 2001. Executives' perceptions of the business value of information technology: A process-oriented approach. Working Paper \#ITR-148. California: Center for Research on Information Technology and Organizations, Graduate School of Management, University of California.

Teo, T. S. H., and W. R. King. 1997. Assessing the impact of integrating business planning and IS planning. Information and Management 30 (6): 309-321.

Teo, T. S. H., and W. R. King. 1999. An empirical study of the impacts of integrating business planning and information systems planning. European Journal of Information Systems 8 (3): 200-210. 